\title{
2-5A-Dependent Ribonuclease
}

National Cancer Institute

\section{Source}

National Cancer Institute. 2-5A-Dependent Ribonuclease. NCI Thesaurus. Code C101337.

2-5A-dependent ribonuclease (741 aa, $\sim 84 \mathrm{kDa}$ ) is encoded by the human RNASEL gene.

This protein plays a role in both RNA processing and the antiviral response. 